Nig. J. Anim. Prod. 2017, 44(4): 307 - 315

(C) Nigerian Society for Animal Production

Nigerian Journal of Animal Production

\title{
Growth performance and nitrogen utilization by West African dwarf goats fed Panicum maximum supplemented with varying ratios of Afzelia africana and Newbouldia laevis
}

Ikhimioya, ${ }^{1}$ I., $*$ Okoruwa, ${ }^{1}$ M. I. and Ikhatua, ${ }^{2}$ U. I.

${ }^{I}$ Department of Animal Science, Ambrose Alli University, P.M.B. 14, Ekpoma, Edo State, Nigeria.

${ }^{2}$ Department of Animal Science, University of Benin, Benin City, Nigeria.

*Correspondence Author e-mail: odionokos@yahoo.com;

Abstract okosmich@gmail.com

Afzelia africana and Newbouldia laevis have recognizable potential as important locally available forage resources but yet to be explored and exploited for ruminants in the tropics. This study was therefore investigated to determine the effect of supplementing varying ratios of Afzelia africana and Newbouldia laevis with Panicum maximum on growth performance and nitrogen utilization of West African dwarf goats. Twenty female West African dwarf goats, aged between 5 and 7 monhs old with an average weight of $6.62 \pm 0.41 \mathrm{~kg}$ were randomly allotted to five dietary treatments with four goats per treatment in a completely randomized design. The treatment diets included $T_{D I}\left(100 \%\right.$ Panicum maximum), $T_{D 2}(25 \%$ Afzelia africana and $75 \%$ Panicum maximum), $T_{D 3}(50 \%$ Afzelia africana and $50 \%$ Panicum maximum), $T_{D 4}\left(25 \%\right.$ Newbouldia laevis and $75 \%$ Panicum maximum) and $T_{D 5}(50 \%$ Newbouldia laevis and $50 \%$ Panicum maximum). A metabolism trial was conducted at the end of the feeding trial to assess the effects of the diets on nitrogen utilization after the growth study on the goats. Results obtained showed that goats on diets $T_{D 3}$ were significantly $(P<0.05)$ higher in terms of final live weight $(9.95 \mathrm{~kg})$, metabolic weights $\left(6.20 \mathrm{LW} \mathrm{W}^{0.75}\right)$, total weight gain $(3.15 \mathrm{~kg})$ and growth rate $\left(35.50 \mathrm{~g} . \mathrm{d}^{-1}\right)$ at $(P<0.01)$ while nitrogen intake $\left(7.86 \mathrm{~g} / \mathrm{d}^{-1}\right)$, metabolic nitrogen intake $\left(1.76 \mathrm{~g} . \mathrm{kg}^{-1} \mathrm{LW} \mathrm{W}^{0.75}\right)$, nitrogen balance $\left(6.81 \mathrm{~g} . \mathrm{d}^{-1}\right)$ were higher $(P<0.001)$ than goats on other diets. Urinary nitrogen output $\left(6.81\right.$ g. $\left.d^{l}\right)$ was significantly $(P<0.01)$ higher in goats on $T_{D 5}$ compared with goats on other diets. No significant $(P>0.05)$ effect in treatment diets with regards to initial and average live weights, faecal nitrogen output, and total nitrogen output with nitrogen retention. It was concluded that goats fed 50\% Afzelia Africana and 50\% Panicum maximum had better nitrogen utilization for growth performance.

Keywords: browse plants, Panicum maximum, growth, nitrogen utilization, goats

\section{Introduction}

Goats are small ruminant livestock that could play an increasing important role in agricultural production system in the tropics. They have beneficial effects on improving family nutrition and their products help in stabilizing household income. Apart from these remarkable benefits, goats are also multipurpose animals that can improve the health status of humans. The provision of good quality forages and or feeds all year round is a major problem of goat production in the tropics and Nigeria in particular. Hence, goats suffer from under feeding especially during the dry season that is characterized by poor quality and unavailability of sufficient forages. The few available forages are usually fibrous and devoid of essential nutrients required for increased rumen microbial fermentation and improve the performance of ruminant livestock in Nigeria (Bamikole et al., 2004). To improve on the productivity of goats and the animal protein intake of the average Nigerian, it therefore become necessary to supplement 


\section{Growth performance and nitrogen utilization by West African dwarf goats}

the seasonal fluctuation in quality of natural forages with alternative feeds. The use of browse plants particularly those based on high yielding nutritive values has been advocated as one of the ways of achieving year round quality feeds for goats. This consideration can therefore be given maximum utilization as they have been identified as potential supplements for ruminants on grass based diet (Mtengeti and Mhelela, 2006). Afzelia africana and Newbouldia laevis have been recognized as important locally available cheap feed resources that can supplement goat feeding in Nigeria (Aye and Adeyeye, 2002; Ikhimioya and Imaseun, 2007). Their quality as browse plants will be most useful during the dry season when most of the pasture grasses become dry and low in nutrients. This is because browse plants in form of trees and shrubs form an integral part of ruminant production (Akinwande $e t$ $a l ., 2017)$. With the limitation in the quality of forages, increasing demand for animal products and importance of browses as fodder for ruminants, it becomes necessary to exploit the potential of some underutilized browse species in the country. Hence, the study was therefore carried out to assess the growth performance and nitrogen utilization by West African dwarf goats fed Panicum maximum supplemented with Afzelia africana and Newbouldia laevis leaves.

\section{Materials and methods Study location}

The study was carried out at the Teaching and Research Farm of the University of Benin, Benin City, Nigeria. The area is located on latitudes $3^{\circ} 8^{\prime}$ and $7^{\circ} 8^{\prime} \mathrm{N}$ and longitudes $3^{0} 2^{\prime}$ and $9^{\circ} 8^{\prime} \mathrm{E}$ within the humid climatic zone of Nigeria. The vegetation of this zone represents an interface between the tropical rainfall and derived savanna.

\section{Preparation of experimental diets}

Panicum maximum was harvested around the Teaching and Research Farm of the University of Benin, Benin City. The succulent and less hardened part of the grass were cut, chopped with a sharp cutlass to about $5 \mathrm{~cm}$ lengths after allowing it to wilt over night. Afzelia africana and Newbouldia laaevis were identified and cut fresh daily from naturally growing stands within and around the university environment. They were defoliated on clean corrugated iron sheets before being measured and fed to the goats. This was to ensure that the goats received only the leaves of the trial plants. Panicum maximum was used as the basal diet in this study while Afzelia africana and Newbouldia laaevis were used as supplements. The percentage ratios of the test leaves of Afzeliz africana and Newbouldia laevis to the basal diet of Panicum maximum in the dietary treatments were 25: 75 and 50: 50 each. Sole intake of Panicum maximum was served as the control group. The five dietary treatments therefore consisted of the following; $\mathrm{T}_{\mathrm{D} 1}$ (100Panicum maximum), $\mathrm{T}_{\mathrm{D} 2}$ (25Afzelia africana : 75 Panicum maximum), $\mathrm{T}_{\mathrm{D} 3}(50$ Afzelia africana : 50Panicum maximum), $\mathrm{T}_{\mathrm{D} 4}(25 N e w b o u l d i a$ laevis : 75Panicum maximum) and $\mathrm{T}_{\mathrm{D} 5}(50$ Newbouldia laevis : 50Panicum maximum)

Experimental animals and their management

Twenty female West African Dwarf goats purchased from the open market within Benin City were used for this experiment. The goats were about $5-7$ months old with body weight of between 5.50 and $9.50 \mathrm{~kg}$ within the first two weeks of their arrival to the farm. The goats' house was cleaned and disinfected prior to their arrival. On their arrival, they were given prophylactic treatment that involved vaccination against Pest des Petite Ruminants and injection of 


\section{Ikihimioya, Okoruwa and Ikhatua}

oxytetracycline (L A) with vitamin B complex intramuscularly at the dosage of $1 \mathrm{ml} / 10 \mathrm{~kg}$ live weight of the animals. They were also dipped in diazintol solution and dewormed with ivomec against ecto and endo parasites respectively. This period was also used to introduce the goats to the test leaves as well as get them used to the confinement. The goats were randomly allotted to the five dietary treatment groups with two replicates of two goats per treatment based on their live weights in a completely randomized design. At the commencement of the study, goats were housed in individual pens measuring $1 \mathrm{x}$ $1.5 \mathrm{~m}$ and identified by wooden tags. Each pen was bedded with wood shavings and with feeders and drinkers on the concrete floor while cleaning of the pens was done weekly. Treatment diets were given to the goats once a day at 09.00 hours with the animals having free access to clean fresh water. The quantity of the leaves offered to each goat was calculated on the basis of $50 \mathrm{gDMkg}^{-1} \mathrm{~d}^{-1}$. The percentage ratios of the test leaves to a basal diet of Panicum maximum were used to determine the proportion of each plant in the daily feed allowance offered to each goat. The weight of the feed offered and that of the feed refusal were used to determine each goat feed intake. Weight of individual goat was measured at the onset of the experiment and subsequently on weekly basis with measuretech ${ }^{\circledR}$ hanging scale until the termination of the trial. On the days of weighing, it was done before the goats were offered feeds. The average weekly live weights of the animals for the 12-weeks trial period were used to calculate their metabolic weights $\left(\mathrm{LW}^{0.75}\right)$. Data derived from initial and final live weight of goats were used to compute total weight gain. The experiment lasted for 102 days after 21-days period of adjustment.

\section{Nitrogen utilization}

At the end of the $10^{\text {th }}$ week of the feeding trial, goats from each dietary treatment were transferred to individual metabolism crates constructed to facilitate the separate collection of faeces and urine. The goats were allowed to adjust to the metabolism crates for 7 days. This was followed by 7 days of data collection on faecal and urinary output as well as measurement of quantity of feed offered and refusals. The daily faecal sample collected was oven dried at $100^{\circ} \mathrm{C}$ for 5hours, cooled, weighed and bulked. About $10 \%$ (aliquots) of the bulked faeces was taken individually and stored for chemical analysis. Urine sample was also collected daily in urinary sample bottles with 4 drops of diluted sulphuric acid $\left(10 \% \mathrm{H}_{2} \mathrm{SO}_{4}\right)$ to prevent loss of nitrogen due to volatilization. Total volume of the urine was determined and $10 \%$ of the urinary sampled was stored in the deep freezer at $-20^{\circ} \mathrm{C}$ until required for analysis. Nitrogen balance by goats was estimated as the difference between nitrogen intake and nitrogen voided from faeces and urine. Nitrogen retention percentage was computed for the nitrogen balance and expressed as a percentage of nitrogen intake (Okoruwa et al., 2014).

\section{Chemical and statistical analysis}

Panicum maximum, Afzelia africana and Newbouldia laevis as well as faecal samples were analysed for proximate composition using the procedure of AOAC (1990). Nitrogen concentration in urine was also analysed using the same methods as reported by AOAC (1990).

Data generated from growth performance and nitrogen utilization were subjected to analysis of variance (Gomez and Gomez, 1984) and significant means were separated by Duncan's (1955) multiple range test.

\section{Results}

Presented in Table 1 is the proximate 


\section{Growth performance and nitrogen utilization by West African dwarf goats}

composition of Panicum maximum and the test plant leaves. Dry matter values that ranged between $30.50 \mathrm{~g} / 100 \mathrm{~g}$ and $42.24 \mathrm{~g} / 100 \mathrm{~g}$ was highest in Newbouldia laevis and lowest in Afzelia africana. Crude protein content was highest in Afzelia africana $(29.85 \mathrm{~g} / 100 \mathrm{~g})$, followed by Newbouldia laevis $(15.67 \mathrm{~g} / 100 \mathrm{~g})$ and Panicum maximum $(8.44 \mathrm{~g} / 100 \mathrm{~g})$ was the lowest. Ash content was lower in Afzelia africana $(6.66 \mathrm{~g} / 100 \mathrm{~g})$ and Newbouldia laevis $(2.49 \mathrm{~g} / 100 \mathrm{~g})$ than Panicum maximum $(12.86 \mathrm{~g} / 100 \mathrm{~g})$. Crude fibre content that had an average value of $19.32 \mathrm{~g} / 100 \mathrm{~g}$ was higher and similar in Afzelia africana $(24.24 \mathrm{~g} / 100 \mathrm{~g})$ and Panicum maximum $(21.34 \mathrm{~g} / 100 \mathrm{~g})$ than Newbouldia laevis $(12.38 \mathrm{~g} / 100 \mathrm{~g})$. The ether extract that ranged between $6.46 \mathrm{~g} / 100 \mathrm{~g}$ and $13.59 \mathrm{~g} / 100 \mathrm{~g}$ was highest in Newbouldia laevis and lowest in Panicum maximum. Nitrogen free extract mean value of $46.06 \mathrm{~g} / 100 \mathrm{~g}$ that varied between $31.31 \mathrm{~g} / 100 \mathrm{~g}$ and $55.98 \mathrm{~g} / 100 \mathrm{~g}$ was highest in Newbouldia followed by Panicum and lowest in Afzelia.

Table 1: Proximate composition $(\mathrm{g} / \mathbf{1 0 0 g})$ of Panicum maximum and the test plant leaves

\begin{tabular}{llll}
\hline Nutrient components & Panicum maximum & Afzelia Africana & Newbouldia laevis \\
\hline Dry matter & 34.72 & 30.50 & 42.24 \\
Crude protein & 8.44 & 29.85 & 15.57 \\
Ash & 12.86 & 6.66 & 2.49 \\
Crude fibre & 21.34 & 24.24 & 12.38 \\
Ether extract & 6.46 & 7.95 & 13.59 \\
Nitrogen free extract & 50.90 & 31.31 & 55.98 \\
\hline
\end{tabular}

The growth performance of West African dwarf goats fed a basal diet of Panicum maximum supplemented with Afzelia africana and Newbouldia laevis is highlighted in Table 2 . The average initial live weights of the animals in the different dietary treatments did not vary significantly $(P>0.05)$, indicating a close weight of the test animals at the start of the experiment. However, the final live weights significantly $(\mathrm{P}<0.05)$ differed with animals on diet $\mathrm{T}_{\mathrm{D} 3}$ being the heaviest on the average with a weight value of $9.95 \mathrm{~kg}$. The lowest mean final live weight value
$(6.63 \mathrm{~kg})$ was recorded with animals on sole Panicum maximum $\left(\mathrm{T}_{\mathrm{D} 1}\right)$ diet. Metabolic body weights of the animals differed significantly $(\mathrm{P}<0.05)$ between the diets. It ranged from a lowest value of $4.53 \mathrm{LW}^{0.75}$ $\left(T_{D 1}\right)$ to a highest value of $6.20 \mathrm{LW}^{0.75}\left(\mathrm{~T}_{\mathrm{D} 3}\right)$. This same pattern in terms of value and statistical significance was observed with total weight gained by the animals. Variations in growth rate between the diets was significant $(\mathrm{P}<0.01)$ with the values 8.84, 11.90, 15.77, 20.54 and 37.50g. $\mathrm{d}^{-1}$ for $\mathrm{T}_{\mathrm{D} 1}, \mathrm{~T}_{\mathrm{D} 5}, \mathrm{~T}_{\mathrm{D} 4}, \mathrm{~T}_{\mathrm{D} 2}$ and $\mathrm{T}_{\mathrm{D} 3}$ diets respectively.

Table 2: Growth performance of West African dwarf goats fed a basal diet of Panicum maximum supplemented with Afzelia africana and Newbouldia laevis

\begin{tabular}{|c|c|c|c|c|c|c|}
\hline \multirow[b]{2}{*}{ Parameters } & \multicolumn{5}{|c|}{ Dietary Treatments } & \multirow[b]{2}{*}{ SEM } \\
\hline & $T_{D 1}$ & $T_{D 2}$ & $T_{D 3}$ & $T_{D 4}$ & $T_{D 5}$ & \\
\hline Initia live weight (kg) & 5.88 & 6.75 & 6.90 & 7.20 & 6.39 & $0.84^{\mathrm{NS}}$ \\
\hline Final live weight (kg) & $6.63^{\mathrm{d}}$ & $8.73^{b}$ & $9.95^{\mathrm{a}}$ & $8.78^{b}$ & $7.38^{c}$ & $0.86^{*}$ \\
\hline Average live weight (kg) & 7.50 & 7.75 & 7.48 & 7.63 & 7.60 & - \\
\hline Metabolic weight ( $\mathrm{LW}^{0.75}$ ) & $4.53^{c}$ & $5.63^{b}$ & $6.20^{\mathrm{a}}$ & $5.66^{\mathrm{b}}$ & $4.57^{\mathrm{c}}$ & $0.49^{*}$ \\
\hline Total weight gain (kg) & $0.73^{\mathrm{c}}$ & $9.98^{b}$ & $3.15^{\mathrm{a}}$ & $1.33^{\mathrm{b}}$ & $1.00^{\mathrm{c}}$ & $0.31^{*}$ \\
\hline Growth rate g. $\mathrm{d}^{-1}$ & $8.84^{\mathrm{c}}$ & $20.54^{b}$ & $37.50^{\mathrm{a}}$ & $15.77^{\mathrm{bc}}$ & $11.90^{\mathrm{c}}$ & $3.88^{* *}$ \\
\hline
\end{tabular}

$\mathrm{T}_{\mathrm{D} 1}=(100$ Panicum maximum $), \mathrm{T}_{\mathrm{D} 2}=(25$ Afzelia africana $: 75$ Panicum maximum $), \mathrm{T}_{\mathrm{D} 3}=(50$ Afzelia africana $: 50$ Panicum maximum $), \mathrm{T}_{\mathrm{D} 4}=(25$ Newbouldia laevis $: 75$ Panicum maximum $), \mathrm{T}_{\mathrm{D} 5}=(50$ Newbouldia laevis $: 50$ Panicum maximum $) \mathrm{SEM}=$ standard error of mean ${ }^{a, b, c, d}=$ means along rows bearing different alphabets differ significantly at the following levels of probabilities, ${ }^{*}=\mathrm{P}<0.05 ;{ }^{* *}=\mathrm{P}<0.01 ; \mathrm{NS}=$ Not significant 


\section{Ikihimioya, Okoruwa and Ikhatua}

Indicated in Table 3 are the measurements reported for nitrogen utilization by goats fed a basal diet of Panicum maximum supplemented with Afzelia africana and Newbouldia laevis. Nitrogen intake differed significantly $(\mathrm{P}<0.01)$ and was highest in diet $\mathrm{T}_{\mathrm{D} 3}\left(7.86 \mathrm{~g} \cdot \mathrm{d}^{-1}\right)$. The solely Panicum maximum diet $\left(\mathrm{T}_{\mathrm{D} 3}\right)$ had the lowest nitrogen intake with a value of $4.96 \mathrm{~g} \cdot \mathrm{d}^{-1}$. Faecal nitrogen output was not significantly different $(\mathrm{P}>0.05)$ and averaged $0.72 \mathrm{~g}$ per day. Urinary nitrogen output values recorded for the different diets were $0.33 \mathrm{~g} . \mathrm{d}^{-1}, 0.21 \mathrm{~g} . \mathrm{d}^{-1}, 0.13 \mathrm{~g} . \mathrm{d}^{-1}$, $0.26 \mathrm{~g} \cdot \mathrm{d}^{-1}$ and $0.45 \mathrm{~g} \cdot \mathrm{d}^{-1}$ for diets $\mathrm{T}_{\mathrm{D} 1}, \mathrm{~T}_{\mathrm{D} 2}, \mathrm{~T}_{\mathrm{D} 3}$
$\mathrm{T}_{\mathrm{D} 4}$ and $\mathrm{T}_{\mathrm{D} 5}$ respectively and differed significantly $(\mathrm{P}<0.05)$. Total nitrogen output from goats on control and test diets that ranged from $0.89 \mathrm{~g} \cdot \mathrm{d}^{-1}\left(\mathrm{~T}_{\mathrm{D} 4}\right)$ to $1.35 \mathrm{~g} \cdot \mathrm{d}^{-1}\left(\mathrm{~T}_{\mathrm{D} 1}\right)$ did not significantly $(\mathrm{P}>0.05)$ vary among the treatment diets. Nitrogen balance was significantly varied between treatment diets with diet $\mathrm{T}_{\mathrm{D} 1}$ having the least value of $3.61 \mathrm{~g} . \mathrm{d}^{-}$ ${ }^{1}$ while the highest value of $6.81 \mathrm{~g} \cdot \mathrm{d}^{-1}$ was recorded in diet $\mathrm{T}_{\mathrm{D} 3}$. There was no significant difference $(\mathrm{P}>0.05)$ between nitrogen retention values of the test diets which ranged from $71.83 \%$ in the $\mathrm{T}_{\mathrm{D} 1}$ (sole Panicum maximum) to $86.66 \%$ in the $\mathrm{T}_{\mathrm{D} 3}$ diet.

Table 3: Nitrogen utilization by West African dwarf goats fed a basal diet of Panicum maximum supplement with Afzedia africana and Newbouldia laevis

\begin{tabular}{|c|c|c|c|c|c|c|}
\hline \multirow[b]{2}{*}{ Parameters } & \multicolumn{5}{|c|}{ Dietary Treatments } & \multirow[b]{2}{*}{ SEM } \\
\hline & $T_{D 1}$ & $T_{D 2}$ & $T_{D 3}$ & $T_{D 4}$ & $T_{D 5}$ & \\
\hline Nitrogen $(\mathrm{N})$ intake $\left(\mathrm{g} . \mathrm{d}^{-1}\right)$ & $4.96^{\mathrm{b}}$ & $5.91^{b}$ & $7.86^{\mathrm{a}}$ & $5.10^{\mathrm{b}}$ & $4.98^{b}$ & $0.45^{* * *}$ \\
\hline Metabolic $\mathrm{n}$ intake & $1.26^{\mathrm{b}}$ & $1.29^{\mathrm{b}}$ & $1.76^{\mathrm{a}}$ & $1.12^{\mathrm{b}}$ & $1.11^{\mathrm{b}}$ & $0.02^{* * *}$ \\
\hline Faecal N output $\left(\mathrm{g} \cdot \mathrm{d}^{-1}\right)$ & 1.02 & 0.93 & 0.93 & 0.06 & 0.67 & $0.29^{\mathrm{NS}}$ \\
\hline Urinary $\mathrm{N}$ output $\left(\mathrm{g} \cdot \mathrm{d}^{-1}\right)$ & $0.33^{\mathrm{ab}}$ & $0.21 b^{c}$ & $0.13^{\mathrm{b}}$ & $0.26^{\mathrm{ab}}$ & $0.45^{\mathrm{a}}$ & $0.07^{* *}$ \\
\hline Total N output $\left(\mathrm{g} \cdot \mathrm{d}^{-1}\right)$ & 1.35 & 1.14 & 1.06 & 0.89 & 1.11 & $0.31^{\mathrm{NS}}$ \\
\hline Nitrogen balance (\%) & $3.61^{\mathrm{b}}$ & $4.77^{b}$ & $6.81^{\mathrm{a}}$ & $4.21^{\mathrm{b}}$ & $3.87^{\mathrm{b}}$ & 0.52 \\
\hline Nitrogen retention (\%) & 71.83 & 80.97 & 86.66 & 82.45 & 77.23 & $6.00^{\mathrm{NS}}$ \\
\hline
\end{tabular}

Metabolic N intake (g.kg+ LW $\left.{ }^{0.75} \mathbf{d}^{-1}\right)$

$\mathrm{T}_{\mathrm{D} 1}=(100$ Panicum maximum $), \mathrm{T}_{\mathrm{D} 2}=(25$ Afzelia africana $: 75$ Panicum maximum $), \mathrm{T}_{\mathrm{D} 3}=(50$ Afzelia africana $: 50$ Panicum maximum $), \mathrm{T}_{\mathrm{D} 4}=25$ Newbouldia laevis $: 75$ Panicum maximum, $\mathrm{T}_{\mathrm{D} 5}=(50$ Newbouldia laevis $: 50$ Panicum maximum $) \mathrm{SEM}=$ standard error of mean

a,b,c $=$ means along rows bearing different alphabets differ significantly at the following le vels of probabilities, ${ }^{*}=\mathrm{P}<0.05$;

${ }^{* * *}=\mathrm{P}<0.01 ;{ }^{* * *}=\mathrm{P}<0.01$; NS = Not significant

\section{Discussion}

Dry matter content that varied between $30.50 \mathrm{~g} / 100 \mathrm{~g}$ in Afzelia africana and 42.24 $\mathrm{g} / 100 \mathrm{~g}$ in Newbouldia laevis appeared somewhat similar to the earlier values reported by Ikhimioya and Imasuen (2007). However, this was contrary to the values (75.71 g/100g - 80.68) g/100g reported by Okah and Antia (2016) for Panicum maximum and mixture of Panicum with browse plants. This comparatively lower values obtained in this study could have been due to species difference. The crude protein content of Panicum $(8.44 \mathrm{~g} / 100 \mathrm{~g})$ was lower than those of Afzelia africana (29.85) $\mathrm{g} / 100 \mathrm{~g}$ and Newbouldia laevis $(15.57 \mathrm{~g} / 100 \mathrm{~g})$. The crude protein of browse expectedly should be higher than that of the grass as it contains higher nitrogen than grass. Crude protein values of browse reported in this study was comparable with the average value of 17.92 $\mathrm{g} / 100 \mathrm{~g}$ reported for browse by Ahamefule $e t$ al. (2006) and higher than the average of $10-$ $12 \mathrm{~g} / 100 \mathrm{~g}$ recommended for maintenance of small ruminants (NRC, 2001). Ash content 


\section{Growth performance and nitrogen utilization by West African dwarf goats}

that ranged from $2.49 \mathrm{~g} / 100 \mathrm{~g}$ to 12.86 $\mathrm{g} / 100 \mathrm{~g}$ was higher in Panicum maximum than the test plant leaves. This implies that the test plant leaves studied might be poor sources of essential mineral elements for ruminants if not used as supplements. The crude fibre content of Panicum (21.3 $\mathrm{g} / 100 \mathrm{~g})$ and Afzelia $(24.24 \mathrm{~g} / 100 \mathrm{~g})$ were higher than that of Newbouldia $(12.38 \mathrm{~g} / 100 \mathrm{~g})$. This difference in crude fibre content explains the amount of cell wall constituents in the feeds in relation to indigestible portion (Abegunde et al., 2014). The higher value of ether extract in Newbouldia laevis (13.59 g/100g) indicated good presence of essential oil than other feeds used in this study. Nitrogen free extract values $(31.31-55.98 \mathrm{~g} / 100 \mathrm{~g})$ recorded in this study were comparable to the average value $(40.90 \mathrm{~g} / 100 \mathrm{~g})$ reported by Ikhimioya and Imasuen (2007).

The investigated diets elicited differences with regards to the final weights of the experimental animals. On the average, animals on Afzelia africana supplemented diets produced better final weights than those on sole Panicum or Newbouldia supplementation. In comparison to the final weights reported in this study, Nguyen Kim Lin et al. (2003) reported higher final weights of $17.05 \mathrm{~kg}, 16.64 \mathrm{~kg}$ and $16.60 \mathrm{~kg}$ for cassava, jackfruit and leucaena respectively when fed with a basal diet of rice bran. Similarly, Suleiman et al. (2016) obtained final weights of between 14.40 and $15.53 \mathrm{~kg}$ from feeding Daniellia oliveri leaf meal in total mixed rations for savannah brown goats.

In terms of total, weight gain, the $50 \%$ Afzelia plus $50 \%$ Panicum diet $\left(\mathrm{T}_{\mathrm{D} 3}\right)$ promoted the best responses in goats as observed in this study. The total weight gains recorded from the diets of this experiment were lower than values reported from small ruminants from a previous study by Suleiman et al. (2016). Aganga et al. (2000) reported a range of 7.5 to $8.5 \mathrm{~kg}$ for Tswana goats fed buffalo grass supplemented with browse plants. The lower values for final weights and weight gain reported in this present study might have resulted from higher dry matter intake in the studies of the aforementioned authors. Average daily gain by the animals in this study was highest from diet $\mathrm{T}_{\mathrm{D} 3}$ and followed by diet $\mathrm{T}_{\mathrm{D} 2}$. Values obtained for growth rates in the test diets were not different in absolute terms. Observed results for this parameter were generally comparable to the range of $8.9-34 \mathrm{~g} . \mathrm{d}^{-1}$ reported for West African dwarf goats fed graded levels of Ficus religiosa with a basal diet of Panicum maximum (Bamikole et al., 2003). Generally, though Aganga et al. (2000) reported higher daily gain by goats, the values were in contrast to reported of this study. Nevertheless, the mean growth rate from the Afzelia supplemented diets in this study were observed to be better than $20 \mathrm{~g} / \mathrm{day}, 22 \mathrm{~g} / \mathrm{day}$ and $20 \mathrm{~g} /$ day obtained from feeding Gliricidia sepium, Leucaena leucocephala and Sesbania grandifolia respectively as supplements to Napier grass (Van Eys et al., 1986). Based on the foregoing, this level of supplementation with Afzelia Africana appears attractive for goat production.

The effect of supplementing Panicum maximum with either Afzelia africana or Newbouldia laevis at different levels of inclusion on nitrogen intake showed that animals on diet $\mathrm{T}_{\mathrm{D} 3}$ consumed more nitrogen compared to the other diets tested which were similar in values. Nevertheless, all the tested diets seemed to provide sufficient nitrogen to maintain all the goats in positive nitrogen balance per day. The highest nitrogen balance obtained in this study therefore indicates that supplementing Panicum maximum with Afzelia africana at a ratio of 50 to 50 is most capable of supplying 


\section{Ikihimioya, Okoruwa and Ikhatua}

sufficient proteins for the maintenance and growth of West African dwarf goats especially during the dry season when the quality of available grasses and most other foliages in general would have dropped. However, Osakwe et al. (2003) reported higher nitrogen intake values than observed in this study from feeding the grass Agrostis stilonifers supplemented with Mangifera indica. The values obtained for nitrogen diets from the trial diets of this study contrast with previously reported lower values from the use of some provenances of Gliricidia sepium as supplements to barely straws (Norton et al., 2000) but were however lower than values obtained for Gliricidia sepium and neem leaves in sheep (Shegun et al., 2017). The higher nitrogen balance observed in the Afzelia africana rather than in the Newbouldia laevis supplemented diets might be associated with higher crude protein content of the former. This effect is in agreement with the findings of Okoruwa et al. (2014) in sheep.

As a percent of nitrogen intake, nitrogen retained by the goats in the trial diets, although were not found to differ between the diets, were relatively high. This is a probable indication of a high nutrient digestibility of the trial diets. However, lower percent nitrogen retention values than what was reported in this study have been reported for Gliricidia sepium (Norton et al., 2000) and for Ficus religiosa (Bamikole et al., 2003).

\section{Conclusion}

Based on the results obtained in this study, growth performance and nitrogen retention on the supplemented dietary treatments were better than those on the sole diet of Panicum maximum. However, growth rate and nitrogen retention were observed to increase with increased inclusion of
Afzelia in the diets. The $50 \%$ Afzelia plus $50 \%$ Panicum diet ratio proved to be the best in terms of growth rate and the retention of nitrogen.

In conclusion, the leaves of Afzelia africana showed a great potential as a feed supplement to Panicum maximum at an inclusion rate of $50 \%$ for goats to enhance performance. Hence, this inclusion level is strongly recommended for small ruminants when there is scarcity of forages in the tropics.

\section{References}

Abegunde, Y. O., Odedire, J. A. and Adegbeye, M. J. 2014. Proximate and anti-nutrient composition of leaves and seeds of some tropical tress and shrubs as feeds for ruminants. Proceedings of $39^{\text {th }}$ Annual Conference of Nigeria Society for Animal Production, $16^{\text {th }}-$ $19^{\text {th }}$ March, help at Babcock University, Ilishan - Remo, Ogun State. Pg. $368-371$.

Aganga, A.A., Adogla-Bessa, T., Omphile, U. J. and Tshireletso, K. 2000. Significances of browses in the nutrition of Tswana goats. Archivos de Zootecnia 49: 469-480.

Ahamefule, F. O., Ibeawuchi, J. A. and Agu C. I. (2006). Comparative evaluation of some forages offered to goats in Umudike, southeastern Nigeria. Journal of Sustainble Tropical agriculture Research 18: $79-86$.

Akinwande, V. O., Make, A., Oyegunwa, A., Adekoyejo, S. and Lawal, A. 2017. Chemical composition of fruit, husk and nut if Terminalia catappa (Indian Almond) as feed supplement for ruminants in the humid tropics. Proceeding of $42^{\text {nd }}$ Annual Conference of Nigeria 
Growth performance and nitrogen utilization by West African dwarf goats

Society for Animal Production, 26 - 30 ${ }^{\text {th }}$ March, held at Landmark University, Onu-Aran, Kwara state, Nigeria. Pg 330-332.

AOAC 1990. Association of Official Analytica Chemists. Official methods of analysis, $15^{\text {th }}$ ed., Washington, DC.

Aye, P. A. and Adeyeye, E. I. 2002. Feed intake and weight changes of West African Dwarf goats fed different levels of afzelia Africana pods. Proceedings of the $27^{\text {th }}$ Annual conference of the Nigeria Society of Animal Production, $17^{\text {th }}-21^{\text {st }}$ march, held at Federal University of Technology, Akure, Nigeria. Pp 212 -213 .

Bamikole, M. A., babayemi, O. J., Arigbede, O. M. and Ikhata, U. J. 2003. Nutritive value of Ficus religiosa in West African Dwarf goats. Animal Feed Science and Technology, 105: 71-79.

Bamikole, M. A., Ikhatua, U. J., Arigbede, O. M., Babayemi, O. J. and Etela, I. 2004. An evaluation of the acceptability as forage of some nutritive and anti-nutritive componenets and of the dry matter degradation profile of five species of Ficus. Tropical Animal Health and Production 36: 157-167.

Duncan, D. B. 1955. Multiple range and multiple F - tests. Biometrics, 11: 1 -42 .

Gomez, K. A. and Gomez, A. A. 1984. Statistical procedures for Agricultural research $\left(2^{\text {nd }}\right.$ ed. In: John Wiley and sons, New York, USA. Pp 680-692.

Ikhimioya, I. and Imasuen, J. A. 2007. Blood profile of West African Dwarf goats fed Panicum maximum supplement withAfzelia Africana and Newbouldia laevis. Pakistan Journal of Nutrition 6(1): 79-84.

Mtengeti, E. J. and Mhelela, A. 2006. Screening of potential indigenous browse species in smei-arid central, Tanzania. A case of Gairo division. Livestock Research for rural Development 18(8): 1-8.

Nguyen Kim Lin, Preston, T. R., Dinh Van Binh and Nguyen Duy Ly 2003. Effects of tree foliages compared with grasses on growth and intestinal nematode infestation in fined goats. In: Reg Preston and Brian Ogle (eds). Proceedings of Final National Seminar - workshop on sustainable livestock production on local feed resources. HUAF - SAREC, Hue City, 25 - 28 march, 2003. Retrieved

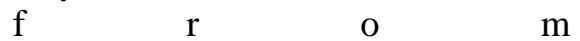
http://www.mekarn.org/sarec03/lin. htm.

Norton, B. W., Wokobi, A. W. and Gutteridge, R. C. 2000. The nutritive value of two provenances of Gliricidia sepium as supplements for goats given low quality straw diets. In: Proceedings of the $7^{\text {th }}$ International Conference on Goats. Held on the $15-21^{\text {st }}$ May at Tours, France. Pp 74-76.

NRC (National Research Council) 2001. Nutrient requirements of small ruminants. 7 threvised edition. National Academy Press, Washington DC.

Okah, U. and Antia, E. A. 2016. Nutritive intake and digestibility of selected browse plants fed in combination with panicum maximum to West African Dwarf (WAD) bucks. Nigerian Journal of Animal Production 43(2): 162-172.

Okoruwa, M. I., Adewumi, M. K., Bamigboye, F. O. and Ikhimioya, I. 


\section{Ikihimioya, Okoruwa and Ikhatua}

2014. Effects of feeding guinea grass and varying levels of avocado seeds with orange peels on nitrogen metabolism and rumen micro organisms in rams. Nigerian Journal of Animal Science, 16(1): $124-132$.

Osakwe, I. I., Steingass, H. and Drochner, W. 2003. The feeding value of Mangifera indica and its effects on crude protein metabolism and energy partitioning when fed to Djallone sheep. Tropical Journal of Animal Science 6(1): 47-54.

Shegun, P. A., Ogbeide, F. O., Edobor, A. E., Okoruwa, M. I. and Ikhimioya, I. 2017. Effect of Gliricidia sepium and neem leaves supplementation on nitrogen metabolism in sheep. Proceedings of $422^{\text {nd }}$ Annual Conference of the Nigeria Society for Animal Production held on $26-30^{\text {th }}$ March at Landmark University, OmuAran, Kwara State, Nigeria. Pp 450 -452 .
Suleiman, A. O., Alemede, I. C., Aremu, A., Olafadehan, O. A. and Muftau, M. A. 2016. Effect of Daniella oliveri leaf meal in total mixed rations on the performance of savannah Brown goats. Nigerian Journal of Animal Production 43(2): $155-161$.

Van Eys, T. E., Mathius, I. W., Pongsapan, P. and Johnson, W. I. 1986. Foliage of the three legumes gliricidia, leucaena and sesbania as supplement to Napier grass for growing goats. Journal of agricultural science 107: $227-233$.

Received: $20^{\text {th }}$ July, 2017

Accepted: $9^{\text {th }}$ December, 2017 